\title{
Evaluation of Two Housekeeping Gene in Diagnosis of Helicobacter Pylori and Compare It to another Routine Test
}

\author{
Saja A. Al-Jumaili ${ }^{1, *}$, Amina N.Althwani ${ }^{2}$, Nawal M. Al-Khalidi ${ }^{3}$ \\ 1, 2 Institute of Genetic Engineering and Biotechnology for Postgraduate Studies / University of Baghdad / Baghdad / \\ Iraq. \\ ${ }^{3}$ Gastroenterology and Hepatology Tertiary Center / Ministry of Health. \\ *Corresponding author. Email: sajoo94@yahoo.com
}

\begin{abstract}
Helicobacter pylori consider as one of the major components of the stomach microbiome, this bacterium is prevalent worldwide and more than half of the world populations are infected with it. Various methods have been developed for the diagnosis and detection of infection with $H$. pylori by using molecular and routine techniques with different levels of specificity and sensitivity. to evaluate and compare two diagnostic methods for the detection of $\mathrm{H}$. pylori bacteria in Iraqi patients, A total of 105 patients and 20 individuals as control with age ranged 17-85 years who attended the gastroenterology and hepatology tertiary center, Baghdad - Iraq, they diagnosed through physicians according to endoscopic findings. Furtherly Biopsy samples from different places were collected by gastroenterologists from each patient, used for histopathological and genetic detection of two Housekeeping gene (16SrRNA and amiA) by PCR technique. Peripheral blood $(3 \mathrm{ml})$ was also withdrawn from patients, then each blood placed into gel tube for separate serum and measure the IgG antibody by ELISA technique. Result: Histological examination' show that 78(74.2\%) were positive for H.pylori , while the detection of $H$. pylori by using molecular method has shown that $69(65.7 \%)$ of the patients were positive for H. pylori by using 16SrRNA gene and only 47 (44.7\%) where positive for amiA gene. By ELISA $92(87.6 \%)$ of patients were positive for IgG antibody. Conclusion: There is no test that we can considered it as golden standard method for the diagnosis' of H.pylori, the combination of more than test is a good choice to achieve the most reliable result.
\end{abstract}

Keywords: Helicobacter pylori, 16S rRNA gene, amiA gene, ELISA

\section{INTRODUCTION}

Helicobacter pylori (H. pylori) is a human gastric. pathogen that usually found in the mucous lining of stomach, it is Gram-negative, microaerophilic bacterium that infects more than $50 \%$ of the world's population and could result in gastrointestinal diseases [1]. H.pylori plays a crucial role in pathogenesis of various illnesses of the digestive system, such a peptic ulcer, gastricadenocarcinoma and chronic gastritis, $H$. pylori is a well-known risk factor for gastric cancer [10]. Different diagnostic strategies developed for the detection of H.pylori infection with both of highly sensitivityand specificity for precise diagnosis of infection with H.pylori in clinical practice. The tests used for Diagnosis are usually divided into invasive (endoscopic-based) such as molecular, histopathological examination. Non-invasive diagnostic method such as serological test that based on the presence of bacterial antibodies [7]. Even though a lot of diagnostic methods are available for now, every test has its limitations, advantages and disadvantages. To pick out one of the methods, could be Relies on the accessibility and availability of tests, laboratories degree, clinical circumstances of the patients and possibility ratio of positivity and negative tests on different clinical circumstance [2].

Helicobacter pylori contain numerous of housekeeping genes that could be useful for the genetic diagnosis of bacteria, $16 S$ rRNA gene is the most common housekeeping genetic marker, amplification method of $16 \mathrm{~S} r R N A$ gene found to be valuable for the identification and phylogeny of the bacteria[11]. Another housekeeping gene N-Acetylmuramoyl-1Alanyl Amidase (AmiA) has 
a chief role in composition and structure of $H$. pylori Peptidoglycan [12].

Table 1. Description of the studied patients.

\begin{tabular}{|c|c|}
\hline $\begin{array}{c}\text { Patients characters } \\
(\mathrm{n}=105)\end{array}$ & Number $(\%)$ \\
\hline Sex & $51(48.57 \%)$ \\
Males & $54(51.42 \%)$ \\
Females & $17-85($ Mean 47$)$ \\
\hline Age (years $)$ & \\
\hline Signs and symptoms & \\
Dyspepsia & $31(29.5 \%)$ \\
Vomiting & $18(17.1 \%)$ \\
Bloating & $10(9.5 \%)$ \\
Weight loss & $17(16.1 \%)$ \\
Loss of appetite & $15(14.2 \%)$ \\
Dysphagia & $12(11.4 \%)$ \\
Melena & $2(1.9 \%)$ \\
& \\
\hline
\end{tabular}

\section{SUBJECTS, MATERIALS AND METHODS}

In a total of 105 patients' (51 males and 54 females) aged 17 to 85 years, they diagnosed through physicians according to' endoscopic findings, complaining' from clinical manifestations of dyspepsia or burning, vomiting, bloating, weight' loss, loss of appetite, dysphagia' and melena were enrolled in this study which was carried out November 2020- Julay 2021 (Table 1).

In addition,' to control group included twenty apparently healthy individuals 9 males' and 11 females; their age matched the patients' group, the participants have no any' gastrointestinal diseases. biopsy samples were collected' by gastroenterologists from 105 patient, four' gastric biopsies were taken from each patient' who underwent upper gastroduodenal endoscopy' in the gastroenterology and hepatology tertiary' center, Baghdad - Iraq.

Three biopsies placed' in formalin for histological examination. The last biopsy has been' placed in $1 \mathrm{ml}$ of normal saline and' preserved in $-20{ }^{\circ} \mathrm{C}$ for molecular analysis, and also blood samples' for serology test were collected from each' patient.

\subsection{Processing of Samples for PCR Assay}

\subsubsection{Extraction of DNA From Biopsy Specimens}

Each biopsy collected was frozen $(-20 \mathrm{c})$. These frozen biopsies' thawed, genomic DNA was then extracted directly from tissue using (Quick Genomic) DNA extraction' kit according to the instructions of manufacturers. The concentration and the purity of DNA were measured by Nano drop.

Table 2. Name and Sequence of Primers

\begin{tabular}{|c|c|c|}
\hline $\begin{array}{c}\text { Name of } \\
\text { Primer }\end{array}$ & Sequence. & $\begin{array}{c}\text { Reference } \\
\text { s }\end{array}$ \\
\hline $\begin{array}{c}16 \mathrm{SrRN} \\
\mathrm{A}\end{array}$ & $\begin{array}{c}5^{\prime}- \\
\text { TTGGAGGGCTTAGTCTCT- } \\
3{ }^{\prime} \\
5 '- \\
\text { AAGATTGGCTCCACTTCA } \\
\text { CA -3' }\end{array}$ & \multirow{2}{*}{$\begin{array}{l}\text { Karam et } \\
\text { al., } 2019\end{array}$} \\
\hline $\operatorname{amiA}$ & $\begin{array}{c}\text { F- 5'- } \\
\text { GTTTTAGACGCTGGGCAT } \\
\text { GG-3' } \\
\text { R-5'- } \\
\text { CCATCAGCAATGCCCTTA } \\
\text { GC-3' }\end{array}$ & \\
\hline
\end{tabular}

\subsubsection{PCR Amplification Analysis}

Detection of H. pylori by two' of Housekeeping Gene Using specific" Primers for 16S rRNA and amiA Genes' for confirmation the presence of $\mathrm{H}$. pylori DNA in collected samples.

Optimization' of PCR for both' genes (16S rRNA' and amiA) were done separately" by using different specific sets of primer. $1 \mu \mathrm{l}$ of each primer, $4 \mu \mathrm{l} \mathrm{DNA}^{\prime}$ sample, and $12.5 \mu \mathrm{l}$ OneTaq master' mix (NEBEngland) and complete' to the final' volume $25 \mu \mathrm{l}$ by using free nuclease water.

The source of all primers' used in this study was IDT ${ }^{\circledR}$ (Belgium). The name and sequence' are given in Table 2. Monoplex PCR reaction for for $16 S$ rRNA and amiA genes using OneTaq $\left(\mathrm{NEB}^{\circledR}\right)$ mastermix are shown in Table 3.

\subsection{Evaluation of $H$. pylori Immunoglobulin $G$}

\section{(IgG) by ELISA}

Serum isolated from 105 blood samples through high-speed centrifuge $6000 \mathrm{rpm}$ ' for 5 mints, H. pylori antibodies was detection by ELISA using Accubind kit from USA [3]. 
Table 3. Monoplex PCR conditions for $16 S$ rRNA and amiA genes

\begin{tabular}{|l|l|l|l|}
\hline $\begin{array}{l}\text { Cycle } \\
\text { No. }\end{array}$ & Stage & Temperature & Time \\
\hline 1 & $\begin{array}{l}\text { Initial } \\
\text { Denaturation }\end{array}$ & $94^{\circ} \mathrm{C}$ & 1 mins \\
\hline $35 \mathrm{x}$ & $\begin{array}{l}\text { Denaturation } \\
\text { Annealing } \\
\text { for } \\
16 \text { SrRNA } \\
\text { Annealing } \\
\text { for amiA } \\
\text { Extension }\end{array}$ & $\begin{array}{l}9{ }^{\circ} \mathrm{C} \\
57^{\circ} \mathrm{C}\end{array}$ & $54^{\circ} \mathrm{C}$ \\
\hline${ }^{\circ} \mathrm{C}$ & 45 sec. \\
\hline 1 & $\begin{array}{l}\text { Final } \\
\text { Extension }\end{array}$ & $70^{\circ} \mathrm{C}$ & 5 sec. \\
\hline
\end{tabular}

\section{RESULT AND DISCUSSION}

The result of present' study clarified that the invasive method by histological test revealed that 78/105 (74.2 $\%$ ) of patients were positive and distributed by different percentage' according to histopathological findings. Histology plays vital role in detecting $H$. pylori and it also furnished more information about the grade of inflamation and related disease, such as atrophy gastritis (AG), gastric cancer and intes tinal metaplasia (IM). Same study done by Karam et al. [18] found that (54.7\%) of samples were' positive by histological test to H. pylori.

Whereas for housekeeping genes 16SrRNA and amiA the result" was 69/105(65.7\%), 47/105 (44.7) respectively, 16S ribosomal RNA' (16SrRNA) gene is could be found in all bacteria, in the same time, it consist of nucleotide sequences that are specific for a given bacterial' genus [13]. the amplification method of 16S rRNA gene found to be useful for the bacterial identification and phylogeny [11]. Numerous features of 16S rRNA gene which make it the "ultimate molecular chronometer" [14], the commonest genetic marker of housekeeping gene, and therefore, a suitable goal for clinically identification and phylogeny [15]. These characteristics comprise the following: Main, it is found in all bacteria; therefore, it is a universal target' for bacterial identification [16]. Additional, the function of this gene hasn't altered through a long time, so random changes of sequence is more likely to reveal the evolutionary modification of microbes (phylogeny) from selected changes which could modify the function of molecules [14]. Lastly, the 16S rRNA gene is big enough, about $1,500 \mathrm{bp}$, for informatics purposes [15][16].
Another housekeeping' gene N-Acetylmuramoyl-1Alanyl Amidase ( AmiA) which has a major role in the structure and composition' of H.pylori Peptidoglycan [12], The result by using this housekeeping was $(47 / 105)$.

The outcome of using' housekeeping genes may due to many factors' such as the site of biopsy wasn't contain the' bacteria, technical factors or others.

several indirect antibody-based tests, such as the serological test which developed for the diagnose of $H$. pylori infection, Because of the small number of bacteria which inhabit the stomach. [17].

In our study, the serological' test $92 / 105$ (87.6\%) of specimens were positive by $\operatorname{IgG}$ antibody, there are many advantages that, serological tests reliability canot affected by gastric atrophy, ulcer bleeding, and antibiotics, that may lead to false negative' results in other tests.

Serological tests not a dependable to evaluate eradication therapy because the levels of antibody could remain in blood for long period even after eradication successfully [4].Because serological test can't differentiate active infection from previous exposure to $\mathrm{H}$. pylori. So, before eradication therapy, other tests is required for further confirmation,

According to Thaker and Moon [3], The sensitivity and specificity of This method is $76-84 \%$ and $79-90 \%$, respectively. like these tests have a high negative predictive value (NPV), based on findings of many studies. The capacity of serological test to detect current infection is depending on many factors such as the infection clinical conditions, the selection of the antigen that used for antibody in ELISA kit, patient's age and the spread of infection [4]. Since serological testes $\mathrm{LgG}$ are less likely confounded by funnel of $H$. pylori by treatments, The serologic methods may be valuable, so this could be useful In patients who treated by colloidal ismuth, antibiotics, and PPIs, if it isn't possible to finish the mentioned medications[4]. Therefore, in particular, the serological method is the efficient diagnostic method specially in clinical states such a gastrointestinal bleeding, gastric carcinoma, MALT lymphoma, and atrophic gastritis. Another advantages offered by Serological testes such as broader accessibility, simplicity, cost-effectiveness and therefore are generally used in most of $\mathrm{H}$. pylori epidemiological studies [5][8].

As well, a serological tests is also found' to be very useful for the evaluation of $H$. pylori infection in children [ 8]. The accuracy of the serological tests is wouldn't affected by ulcer bleeding and' gastric atrophy, which may lead to false-negative results' in another invasive or non-invasive experiments, this can be consider as another advantage of the serological test [6]. 
With the development of H.pylori infection therapies, the diagnostic methods have also been' expanded. In spite of this, the standard methods applicable, especially in the population who are at risk, is still missing [2 ].

\section{CONCLUSION}

There is no test that we can considered it as golden standard method for the diagnosis' of H.pylori, the combination of more than test is a good choice to achieve the most reliable result.

\section{REFERENCES}

[1] J.K.Y. Hooi, W.Y. Lai, W.K. Ng, et al. Global prevalence of Helicobacter pylori infection: systematic review and meta-analysis. Gastroenterology, 2017;153:420-429.

[2] B. Kalali, L. Formichella, M. Gerhard, Diagnosis of Helicobacter pylori: changes towards the future Diseases, 2015, 3(3):122-135.

[3] Y. Thaker, A.Moon, A. Afzali, Helicobacter pylori: a review of epidemiology, treatment and management, J Clin Gastroenterol, 2016, 2(19):1-5.

[4] P. Malfertheiner, F. Megraud, C.A. O'morain, J. Atherton, A.T. Axo, F. Bazzoli, G.F. Gensini, J.P. Gisbert, D.Y. Graham, T. Rokkas, Management of Helicobacter pylori infection-the Maastricht IV/Florence consensus report. Gut, 2012, 61(5):646-664.

[5] Jemilohun AC, Otegbayo JA. Helicobacter pylori infection:past, present and future. Pan Afr Med J 23(1) Ueda J, Okuda M, Nishiyama T, Lin Y, Fukuda Y, Kikuchi S.Diagnostic accuracy of the Eplate serum antibody test kit indetecting Helicobacter pylori infection among Japanese child ren.J Epidemiol 2016;24:47-51.

[6] Wang HJ, Cheng WC, Cheng $\mathrm{HH}$, Lai CH, Wang WC. Helicobacter pylori cholesteryl glucosides interfere with host membrane phase and affect type IV secretion system function during infection in AGS cells. Mol Microbiol 2012; 83: 67-84.

[7] Vaira, L. Gatta, C. Ricci et al., "A comparison amongst three rapid urease tests to diagnose Helicobacter pylori infection in 375 consecutive dyspeptic," Internal and Emergency Medicine, 2010; 5, 1: 41-47.

[8] Ueda J, Okuda M, Nishiyama T, Lin Y, Fukuda Y, Kikuchi S. Diagnostic accuracy of the E-plate serum antibody test kit in detecting Helicobacter pylori infection among Japanese children. J Epidemiol 2014; 24(1):47-51.
[9] Gravina A. G., Priadko K., Ciamarra P., Granata L., Facchiano A., Miranda A., et al. . Extra-gastric manifestations of Helicobacter pylori infection. J Clin Med. 2020; 9 (12), 3887.

[10] Bray, F., Ferly, J., Soerjomataram, I., Siegel, RL. Torre, LA., and Jemal, A. GLOBOCAN estimates of incidence and mortality worldwide for 36 cancers in 185 countries. CA Cancer J Clin. 2018; 68(6), 394-424.

[11] Hadeel Gassim Hassan,1 Maryam Atif Salaheldin Ali,1 Sulafa Mohamed Eltaher,2 Leena Babiker Idris,3 Hisham N. Altayb,4 Amin Mohamed Abass,5 Mustafa Mohammed Ahmed Ibrahim,6 ElAmin Mohamed Ibrahim, 1 and Mohamed A. Hassan 2020 . Molecular Phylogenetic Analysis of 16S rRNA Sequences Identified Two Lineages of Helicobacter pylori Strains Detected from Different Regions in Sudan Suggestive of Differential Evolution. International Journal of Microbiology. Hindawi International Journal of Microbiology, 2020; 8825718, (12).

[12] Catherine Chaput, Chantal Ecobichon, Nadine Pouradier, Jean-Claude Rousselle, Abdelkader Namane, and Ivo G. Boneca. Role of the NAcetylmuramoyl-1-Alanyl Amidase, AmiA, of Helicobacter pylori in Peptidoglycan Metabolism, Daughter Cell Separation, and Virulence MICROBIAL DRUG RESISTANCE, 2016; (22) 6.

[13] Smith SI, Oyedeji KS, Arigbabu AO, Cantet F, and Megraud F. Comparison of three PCR methods for detection of Helicobacter pylori DNA and detection of cagA gene in gastric biopsy specimens. World J Gastroenterol, 2004, 10;19581960.

[14] C. R. Woese, "Bacterial evolution," Microbiological Reviews, 1987;( 51) 2, 221-271.

[15] J. M. Janda and S. L. Abbott, "16S rRNA gene sequencing for bacterial identification in the diagnostic laboratory: pluses, perils, and pitfalls," Journal of Clinical Microbiology, 2007;( 45) 9, 2761-2764.

[16] J. Patel, "16S rRNA gene sequencing for bacterial pathogen identification in the clinical laboratory," Molecular Diagnosis, 2001; (6) 4, 313-321.

[17] C. Burucoa, J.-C. Delchier, A. Courillon-Mallet et al., "Comparative evaluation of 29 commercial Helicobacter pylori serological kits," Helicobacter, 2013; (18) 3, 169-179.

[18] Karam D. Salman, Amina N. Al-Thwaini, Ilham A. Khalaf, Bassim A.Askar. Designing of molecular tool for the detection of helicobacter pylori in Iraqi patients using multiplex PCR technique. Annals of Tropical Medicine \& Public Health, 2019: 22 (9). 